\title{
Comparison of the Chemical Properties of Forest Soil from the Silesian Beskid, Poland
}

\author{
Maria Zołotajkin, ${ }^{1}$ Adam Smoliński, ${ }^{2}$ Jerzy Ciba, ${ }^{1}$ Joanna Kluczka, ${ }^{1}$ and Monika Skwira ${ }^{1}$ \\ ${ }^{1}$ Faculty of Chemistry, Silesian University of Technology, B. Krzywoustego Street 6, 44-100 Gliwice, Poland \\ ${ }^{2}$ Department of Energy Saving and Air Protection, Central Mining Institute, Pl. Gwarków 1, 40-166 Katowice, Poland
}

Correspondence should be addressed to Maria Zołotajkin; maria.zolotajkin@polsl.pl

Received 20 May 2013; Revised 15 October 2013; Accepted 19 November 2013; Published 30 January 2014

Academic Editor: Athanasios Katsoyiannis

Copyright (C) 2014 Maria Zołotajkin et al. This is an open access article distributed under the Creative Commons Attribution License, which permits unrestricted use, distribution, and reproduction in any medium, provided the original work is properly cited.

\begin{abstract}
There is spruce forests degradation observed in the Silesian Beskid. The aim of the work was the assessment of parameters diversifying organic layers of soils in two forest areas: degraded and healthy spruce forests of Silesian Beskid. 23 soil samples were collected from two fields-14 soil samples from a degraded forest and 9 soil samples from a forest, where pandemic dying of spruce is not observed. Implementation of hierarchical clustering to experimental data analysis allowed drawing a conclusion that the two forest areas vary significantly in terms of content of aluminium extracted with solutions of barium chloride $\left(\mathrm{Al}_{\mathrm{exch}}\right)$, sodium diphosphate $\left(\mathrm{Al}_{\mathrm{pyr}}\right)$, and $\mathrm{pH}_{\mathrm{KCl}}$ and in the amount of humus in soil.
\end{abstract}

\section{Introduction}

Aluminosilicates comprise most of the aluminium minerals in soil. The natural processes of aluminosilicates weathering lead to their conversion or decomposition. Temperature, air, and water are the factors influencing the above-mentioned transformations. Industrial development in the 20th century, resulting in higher concentration of nitrogen and sulphur oxides in the atmosphere, facilitated the processes of aluminosilicates decomposition in soil. Changes in soil solutions, decrease in soil $\mathrm{pH}$ and in the content of metal cations as $\mathrm{Na}^{+}, \mathrm{K}^{+}, \mathrm{Ca}^{2+}$, and $\mathrm{Mg}^{2+}$, and a considerable increase in the content of various ionic forms of aluminium are observed.

In 1980 Ulrich et al. [1] claimed that an increase in aluminium content in a soil solution is one of the main reasons for forests extinction. Until now, however, it is not clear which of the aluminium forms are phytotoxic. The aqua complex of aluminium $\mathrm{Al}\left(\mathrm{H}_{2} \mathrm{O}\right)_{6}{ }^{3+}$ is considered to be the main phytotoxic component $[2,3]$. Toxic properties of aqua hydroxo complexes $\mathrm{Al}(\mathrm{OH})\left(\mathrm{H}_{2} \mathrm{O}\right)_{5}{ }^{2+}$ and $\mathrm{Al}(\mathrm{OH})_{2}\left(\mathrm{H}_{2} \mathrm{O}\right)_{4}{ }^{+}$ are often reported in the literature as well as particularly phytotoxic characteristic of aluminium polymeric hydroxo complexes $\left(\mathrm{Al}_{13}{ }^{7+}\right)$ [2-12]. Fluoride, sulphate, and organic complexes of aluminium are generally considered harmless, although some authors report toxic properties of the two first ones $[2,4,7,12,13]$.

The toxic properties of aluminium depend not only on the absolute content of its inorganic complexes in soil, but also on the proportion of aluminium ions in the sum of exchangeable cations (CEC-cation exchange capacity). According to Ulrich et al. [1], an increase in the aluminium share to over $30 \%$ of CEC is the main reason for forests extinction. Use of the so-called chemical toxicity indicators, that is, molar ratios of selected cations and aluminium, for example, $F_{1}=\mathrm{Ca}_{\text {exch }} / \mathrm{Al}_{\text {exch }}<1\left(\mathrm{cmol} \mathrm{kg}{ }^{-1}\right) /\left(\mathrm{cmol} \mathrm{kg}^{-1}\right)$, $F_{2}=\mathrm{Mg}_{\text {exch }} / \mathrm{Al}_{\text {exch }}<0.1\left(\mathrm{cmol} \mathrm{kg}^{-1}\right) /\left(\mathrm{cmol} \mathrm{kg}^{-1}\right)$, or $F_{3}=$ $\mathrm{Ca}_{\text {exch }} /\left(\mathrm{Ca}_{\text {exch }}+\mathrm{Al}_{\text {exch }}+\mathrm{Fe}_{\text {exch }}\right)<0.05\left(\mathrm{cmol} \mathrm{kg}^{-1}\right) /(\mathrm{cmol}$ $\left.\mathrm{kg}^{-1}\right)$, is controversial according to some authors $[1,4,14-$ 16]. The ratios $F_{4}=\left(\mathrm{Ca}_{\text {exch }}+\mathrm{Mg}_{\text {exch }}+\mathrm{K}_{\text {exch }}\right) / \mathrm{Al}_{\text {exch }}(\mathrm{cmol}$ $\left.\mathrm{kg}^{-1}\right) /\left(\mathrm{cmol} \mathrm{kg}^{-1}\right)[17,18]$ and $F_{5}=\left(\mathrm{Ca}_{\text {exch }}+\mathrm{Mg}_{\text {exch }}+\mathrm{K}_{\text {exch }}\right.$ $\left.+\mathrm{Mn}_{\text {exch }}+\mathrm{Fe}_{\text {exch }}\right) / \mathrm{Al}_{\text {exch }}\left(\mathrm{cmol} \mathrm{kg}^{-1}\right) /\left(\mathrm{cmol} \mathrm{kg}^{-1}\right)[19,20]$ are used as another toxicity indicators.

The Silesian Beskid is a part of West Beskid (West Carpathians). The area has been exposed to acid rains for years as coal-fired power stations (Rybnik Coal District in Poland and Ostrava-Karvina coal and mining region in 
TABLE 1: Average annual loads $\left(\mathrm{kg} \cdot \mathrm{ha}^{-1}\right)$ contributed by the precipitation of $\mathrm{SO}_{4}$ and $\left(\mathrm{NO}_{3}+\mathrm{NO}_{2}\right)$ in Silesia.

\begin{tabular}{lcc}
\hline Year & \multicolumn{2}{c}{ Average annual loads $\left(\mathrm{kg} \cdot \mathrm{ha}^{-1}\right)$} \\
$\mathrm{SO}_{4}$ & $\mathrm{NO}_{3}+\mathrm{NO}_{2}$ \\
\hline 1999 & 33.00 & 4.86 \\
2000 & 35.93 & 5.50 \\
2001 & 33.59 & 4.96 \\
2002 & 27.76 & 3.85 \\
2003 & 21.20 & 3.56 \\
2004 & 24.50 & 4.00 \\
2005 & 23.00 & 4.40 \\
2006 & 20.25 & 3.60 \\
2007 & 25.13 & 4.06 \\
2008 & 20.42 & 3.61 \\
2009 & 22.33 & 3.73 \\
2010 & 23.63 & 4.16 \\
2011 & 19.25 & 3.43 \\
2012 & 17.70 & 3.39 \\
\hline
\end{tabular}

Czech Republic), Trzyniec steel plant (Czech Republic) and Katowice agglomeration (Poland) are located in its close vicinity. It is also an attractive tourist destination which results in heavy traffic. In Table 1, we present the average annual loads $\left(\mathrm{kg} \cdot \mathrm{ha}^{-1}\right)$, contributed by the precipitation of sulphates (VI) and the sum of nitrates $\left(\mathrm{NO}_{3}+\mathrm{NO}_{2}\right)$ in Silesia (The Silesian Voivodeship) where Beskid Slaski is located [21]. Forests spruce monocultures introduced in the 19th century dominate Silesian Beskid.

The spruce forest stands in Silesian Beskid have been heavily affected by decline in recent years. The youngest sprouts are prematurely yellowed and lose their needles, the trees' crowns are dwindled, and eventually the trees wither. Pests' plaque, like insects (xylophages Ips typographus), fungi (honey fungus Armillaria mellea), and so forth, spread. Deforestation is carried out on large areas to save uninfected trees.

In our previous papers the prediction of aluminium content in the soil of the Beskid mountain region was discussed $[22,23]$. The aim of this study was the comparison of selected chemical properties of soil collected from two forest areas. The first object (Istebna) was the devastated area where spruce dieback, invasion of insects and fungi were observed and intensive sanitation felling was leading. The second object (Bukowiec) was healthy spruce forest without any dying of spruce. To select the parameters distinguishing these two areas, the hierarchical clustering analysis was used.

\section{Materials and Methods}

2.1. Soil Samples. Soil samples were collected at Wisła Forest District lying within the Silesian nappe. Its main trunk is Istebna and Godula sandstone. Acid brown soil was derived from this bedrock.

The data set studied included measurements of 13 chemical parameters in 23 soil samples collected from the organic layer O. Fourteen samples were collected in Istebna (along the mountain traverse) on the area of about 5 ha of spruce forest, infected with insect pests (xylophages), under deforestation. Three samples were taken at the same height in the land stripe of $200 \mathrm{~m}$ (every about $100 \mathrm{~m}$ ). The heights of sampling points were from 690 to $850 \mathrm{~m}$ above sea level. In Bukowiec nine samples were taken on the area of about 2 ha 120 -year-old spruce healthy forest, along the traverse from 645 to $720 \mathrm{~m}$ above the sea level.

The samples were dried in air, $2 \mathrm{~mm}$ sieved, and assayed for $\mathrm{pH}_{\mathrm{KCl}}$ potentiometrically [24]; organic matter content $\mathrm{w}_{\text {org }}(\% \mathrm{w} / \mathrm{w})$ by combustion of a soil sample in a furnace at $500-550^{\circ} \mathrm{C}$ to constant mass [24]; total carbon $\mathrm{C}_{\text {tot }}(\%$ $\mathrm{w} / \mathrm{w})$; total nitrogen $\mathrm{N}_{\text {tot }}(\% \mathrm{w} / \mathrm{w})$ with the use of instrumental method on PE CHNS/O 2400 (Perkin Elmer) device and $\mathrm{C}_{\text {tot }}\left(\mathrm{N}_{\text {tot }}\right)^{-1}$ ratio; cation exchange capacity CEC $\left(\mathrm{cmol}_{\mathrm{c}} \mathrm{kg}^{-1}\right)$ according to ISO 11260 [25], based on Gillman's method [26]; contents of calcium $\mathrm{Ca}_{\text {exch }}\left(\mathrm{cmol}_{\mathrm{c}} \mathrm{kg}^{-1}\right)$; magnesium $\mathrm{Mg}_{\text {exch }}\left(\mathrm{cmol}_{\mathrm{c}} \mathrm{kg}^{-1}\right)$; potassium $\mathrm{K}_{\text {exch }}\left(\mathrm{cmol}_{\mathrm{c}} \mathrm{kg}^{-1}\right)$; iron $\mathrm{Fe}_{\text {exch }}\left(\mathrm{cmol}_{\mathrm{c}} \mathrm{kg}^{-1}\right)$, and manganese $\mathrm{Mn}_{\text {exch }}\left(\mathrm{cmol}_{\mathrm{c}} \mathrm{kg}^{-1}\right)$ in the exchangeable fraction by metal content determination with the use of AAS method in $\left(0.1 \mathrm{moll}^{-1}\right) \mathrm{BaCl}_{2}$ soil extracts [25].

Aluminium was extracted with solutions of barium chloride and sodium pyrophosphate. Exchangeable aluminium (which reflects $\mathrm{Al}^{3+}$ in soil solution) was extracted with $0.1 \mathrm{moll}^{-1}$ solution of barium chloride $\mathrm{Al}_{\text {exch }}(\mathrm{v} / \mathrm{m}(\mathrm{v} / \mathrm{m}=$ ratio of extraction solvent volume $\left(\mathrm{cm}^{3}\right)$ to mass of air-dried soil sample $(\mathrm{g}))=12$, extraction time-3 hours) [25]. Aluminium $\mathrm{Al}_{\text {pyr }}$ extracted with $0.1 \mathrm{moll}^{-1}$ solution of $\mathrm{Na}_{4} \mathrm{P}_{2} \mathrm{O}_{7}$ $(\mathrm{v} / \mathrm{m}=50$, extraction time-16 hours) is considered to be the form associated with the soil organic matter in a sample. Aluminium content in extracts was determined with the use of AAS method and Varian SPECTRA AA880 device. The measurements' accuracy was tested with a certified material GSJ JSO-2 $21.34 \pm 0.19 \% \mathrm{Al}_{2} \mathrm{O}_{3}$.

Each assay was repeated at least 3 times. The results are given in Table 2.

2.2. Data Analysis. Hierarchical clustering analysis is a method which can be applied to multidimensional data sets, in order to study similarities of objects (e.g., soil samples) in the variables' space (e.g., parameters), or similarities of variables in the objects space [27-30]. Cluster analysis is characterized by the similarity measure used and the way the resulting subclusters are linked. The most popular similarity measure is Euclidean distance, whereas among the linkage methods the most popular ones are single linkage, complete linkage, average linkage, centroid linkage, and Ward linkage. In the study the Ward linkage was used. It is based on the inner squared distance of clusters, so that at each stage these two clusters are merged, for which the minimum increase in the total within group error sums of squares is observed. The results of hierarchical clustering are presented in a form of a dendrogram, along which $x$ axis indices of clustered objects (or variables) are displayed, and which $y$ axis shows the corresponding linkage distances (or an adequate measure of similarity) between the two objects or clusters, which 
TABLE 2: Range, average, and median of parameters measured in soil of Silesian Beskid.

\begin{tabular}{|c|c|c|c|c|c|c|c|c|}
\hline \multirow{2}{*}{ Number } & \multirow{2}{*}{ Parameter } & \multicolumn{3}{|c|}{ Istebna } & \multicolumn{3}{|c|}{ Bukowiec } & \multirow{2}{*}{ SD } \\
\hline & & Range & Mean & Median & Range & Mean & Median & \\
\hline 1 & $\mathrm{pH}_{\mathrm{KCl}}$ & $2.84-3.39$ & 3.07 & 3.10 & $2.57-2.91$ & 2.80 & 2.81 & 0.02 \\
\hline 2 & $\mathrm{C}_{\text {tot }}(\% \mathrm{w} / \mathrm{w})$ & $5.2-26.2$ & 15.3 & 14.6 & $9.7-44.0$ & 21.7 & 21.1 & 0.05 \\
\hline 3 & $\mathrm{~N}_{\text {tot }}(\% \mathrm{w} / \mathrm{w})$ & $0.18-1.12$ & 0.70 & 0.68 & $0.32-1.38$ & 0.79 & 0.76 & 0.04 \\
\hline 4 & $\mathrm{Ca}_{\text {exch }}\left(\mathrm{cmol}_{\mathrm{c}} \mathrm{kg}^{-1}\right)$ & $0.11-2.81$ & 0.80 & 0.45 & $0.14-3.51$ & 1.32 & 0.75 & \\
\hline 5 & $\operatorname{Mg}_{\text {exch }}\left(\mathrm{cmol}_{\mathrm{c}} \mathrm{kg}^{-1}\right)$ & $0.11-1.15$ & 0.45 & 0.42 & $0.13-0.56$ & 0.30 & 0.31 & \\
\hline 6 & $\mathrm{~K}_{\text {exch }}\left(\mathrm{cmol}_{\mathrm{c}} \mathrm{kg}^{-1}\right)$ & $0.09-0.52$ & 0.34 & 0.35 & $0.18-0.49$ & 0.32 & 0.29 & \\
\hline 7 & $\mathrm{Fe}_{\mathrm{exch}}\left(\mathrm{cmol}_{\mathrm{c}} \mathrm{kg}^{-1}\right)$ & $0.36-1.44$ & 0.77 & 0.74 & $0.42-0.94$ & 0.60 & 0.54 & \\
\hline 8 & $\mathrm{Mn}_{\text {exch }}\left(\mathrm{cmol}_{\mathrm{c}} \mathrm{kg}^{-1}\right)$ & $0.01-0.09$ & 0.04 & 0.03 & $0.003-0.12$ & 0.05 & 0.04 & \\
\hline 9 & $\mathrm{Al}_{\text {exch }}\left(\mathrm{cmol}_{\mathrm{c}} \mathrm{kg}^{-1}\right)$ & $7.10-19.08$ & 12.41 & 11.75 & $6.09-11.81$ & 9.03 & 9.15 & 0.28 \\
\hline 10 & $\mathrm{Al}_{\mathrm{pyr}},\left(\mathrm{mg} \mathrm{kg}^{-1}\right)$ & $1804-4805$ & 2780 & 2546 & $1177-2843$ & 1764 & 1690 & 93 \\
\hline 11 & $w_{\text {org }},(\% \mathrm{w} / \mathrm{w})$ & $11.9-51.4$ & 32.1 & 31.4 & $17.4-84.8$ & 41.9 & 40.9 & 1 \\
\hline 12 & CEC, $\left(\mathrm{cmol}_{\mathrm{c}} \mathrm{kg}^{-1}\right)$ & $9.48-19.83$ & 15.60 & 15.55 & $9.67-18.87$ & 15.03 & 15.50 & 1.5 \\
\hline 13 & $\mathrm{C}_{\text {tot }} / \mathrm{N}_{\text {tot }}$ & $17.4-29.6$ & 22.3 & 21.8 & $22.8-31.5$ & 27.5 & 28.4 & \\
\hline
\end{tabular}

are merged. The dendrogram reveals data structure (i.e., the subgroups of objects), but it allows no interpretation of the observed patterns in terms of the original variables (parameters). Therefore a simple visualization method was proposed, using colour map, which represents the studied data organized in matrix $\mathbf{X}(m \times n)$, but with objects and parameters ordered according to specific object and variable order (called "objorder" and "varorder", resp.) from the Ward dendrograms [30].

The hierarchical cluster analysis was performed for parameters $1-10$. The studied data were organized in matrix $\mathbf{X}(23 \times 10)$; that is, each row of matrix $\mathbf{X}$ represented one soil sample described by the first 10 parameters (Table 2). The data set was standardized as the measured parameters significantly differed in their ranges:

$$
x c_{i j}=\frac{\left(x_{i j}-\bar{x}_{j}\right)}{s_{j}},
$$

where $\bar{x}_{j}, s_{j}$ denote the mean of the $j$ th column and its standard deviation, respectively.

\section{Results and Discussion}

The soil samples were taken from the layer O. The organic matter content varied widely from over a dozen to tens percent and was strongly correlated with the total carbon content, $\mathrm{C}_{\mathrm{tot}}\left(R^{2}=0.9838\right)$.

In both locations (Bukowiec and Istebna) (Table 2),

(i) the exchangeable aluminium content was considerably higher than the toxicity level $1.11 \mathrm{cmol}_{\mathrm{c}} \mathrm{kg}^{-1}$ [4], and equaled on average $12.4 \mathrm{cmol}_{\mathrm{c}} \mathrm{kg}^{-1}$ in Istebna and $9.0 \mathrm{cmol}_{\mathrm{c}} \mathrm{kg}^{-1}$ in Bukowiec;

(ii) aluminium content in CEC considerably exceeded the critical level by $30 \%$ (Figure 1) [1];

(iii) the soils were very acid.

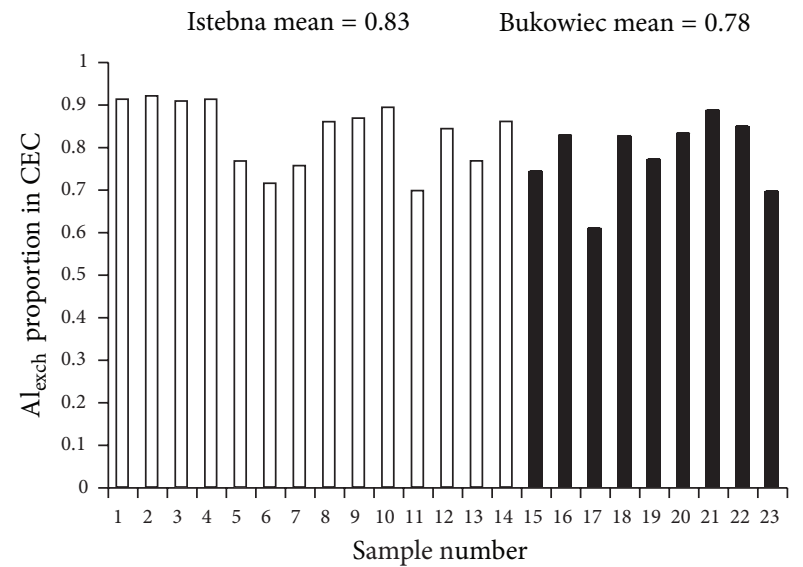

FIgUre 1: Aluminium proportion in CEC.

To explore the studied data set and to examine the similarities of the sampling sites, the hierarchical clustering methods were used. The results of the analysis presented below were based on the Euclidean distance and the Ward linkage algorithm. Clustering of the sampling sites in the parameter space described in Table 2 was presented in Figure 2.

The dendrogram shown in Figure 2(a) did not reveal the differences between soil samples collected in healthy and infected forest areas. It revealed, however, two district clusters of sampling sites; cluster A, containing all soil samples collected in Bukowiec (healthy forest), mixed with some of soil samples collected in Istebna (objects numbers 5-7, 1113) and cluster B, containing the remaining soil samples from the infected Istebna forest. Moreover, two subclusters can be distinguished in the main cluster A: the first one $\left(A_{I}\right)$ with soil samples numbers 5, 7, and 11-13 from Istebna and soil samples numbers 15, 16, 18, and 20-22 from Bukowiec and the second one $\left(A_{\text {II }}\right)$, with soil sample number 6 from Istebna and soil samples numbers 17, 19, ad 23 from Bukowiec. 


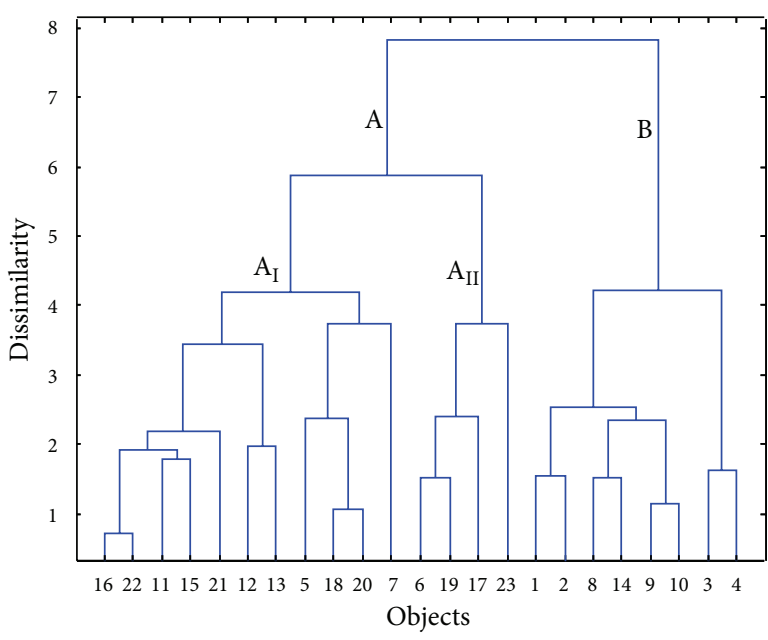

(a)

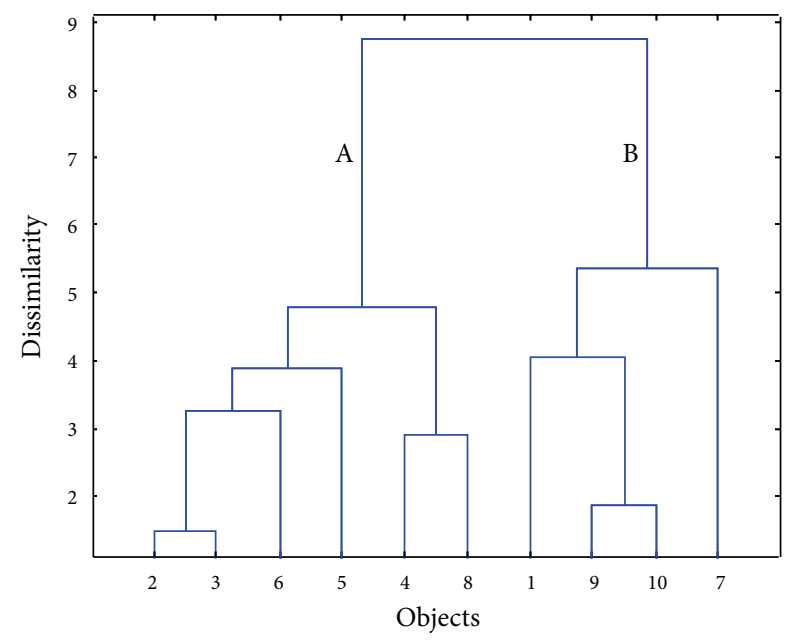

(b)

FIGURE 2: Dendrograms of (a) sampling sites in the space of 10 measured parameters and (b) variables in the objects space.

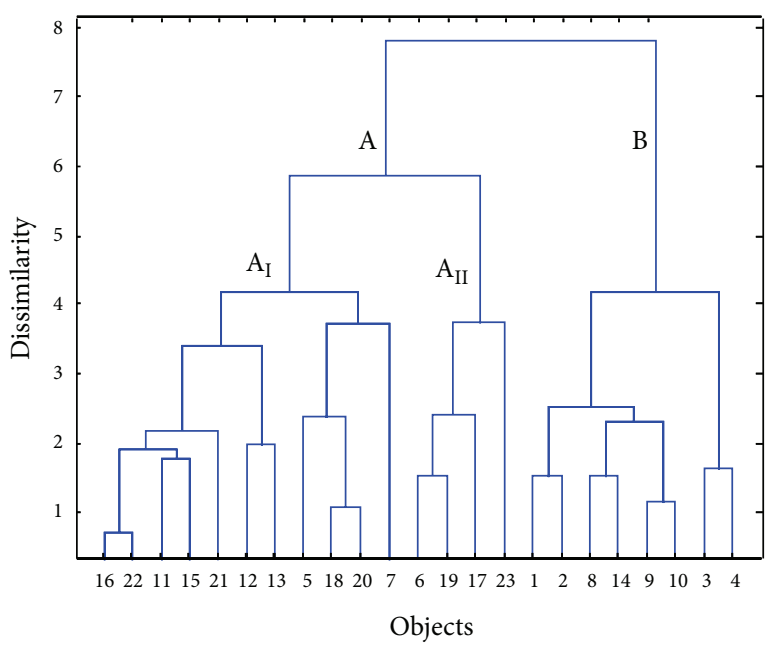

(a)

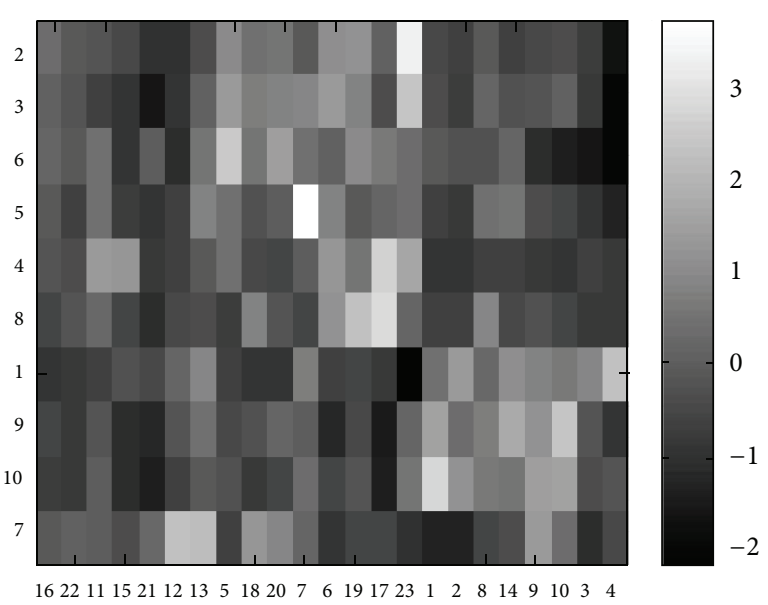

(b)

FIgURE 3: Dendrogram of samples with visual complement in the space of ten parameters.

The dendrogram constructed for the variables (see Figure 2(b)) revealed two main classes thereof (A and B): class A, including variables numbers $2-6$ and 8 , which represented the total carbon and nitrogen contents and concentrations of $\mathrm{Ca}_{\text {exch }}, \mathrm{Mg}_{\text {exch }}, \mathrm{K}_{\text {exch }}, \mathrm{Mn}_{\text {exch }}$, respectively and class $\mathrm{B}$, constituted by variables numbers $1,7,9$, and $10\left(\mathrm{pH}_{\mathrm{KCl}}, \mathrm{Fe}_{\text {exch }}\right.$, $\mathrm{Al}_{\text {exch }}$, and $\mathrm{Al}_{\text {pyr }}$ ).

The dendrogram of objects (soil samples) with the image of the data set with objects and variables sorted according to the "objorder" and "varorder" was presented in Figure 3. Simultaneous interpretation of the dendrogram of objects in variable space and the image of the data allowed drawing a conclusion that soil samples belonging to cluster A were characterized by relatively lower $\mathrm{pH}_{\mathrm{KCl}}$ and lower concentrations of $\mathrm{Al}_{\mathrm{pyr}}$ (parameters numbers 1 and 10). Moreover, the uniqueness of subcluster $A_{I}$ can be explained by relatively high concentration of $\mathrm{Fe}_{\text {exch }}$ (parameter number 7), whereas the uniqueness of subcluster $A_{\text {II }}$ stemmed from relatively high total carbon and nitrogen contents (parameters numbers 2 and 3) and the highest concentrations of $\mathrm{Ca}_{\text {exch }}$ from all tested soil samples. Soil samples belonging to cluster B were characterized by higher $\mathrm{pH}_{\mathrm{KCl}}$ and concentrations of $\mathrm{Al}_{\text {exch }}$ and $\mathrm{Al}_{\text {pyr }}$ (parameters numbers 1,9 , and 10).

Another cluster models were constructed in order to find the basic soil parameters distinguished between the two studied forest areas. Clustering of the soil sampling sites in the parameter space described by $\mathrm{pH}_{\mathrm{KCl}}$, total carbon content $\mathrm{C}_{\text {tot }}$, exchangeable aluminium content $\mathrm{Al}_{\text {exch }}$, and organically bound aluminium content $\mathrm{Al}_{\text {pyr }}$ was presented in Figure 4.

The dendrogram constructed for soil samples in the space of four parameters allowed revealing the differences between soil samples collected in healthy and infected forests. Cluster A included all soil samples collected in healthy Bukowiec forest (objects numbers 15-23) with three soil samples from 


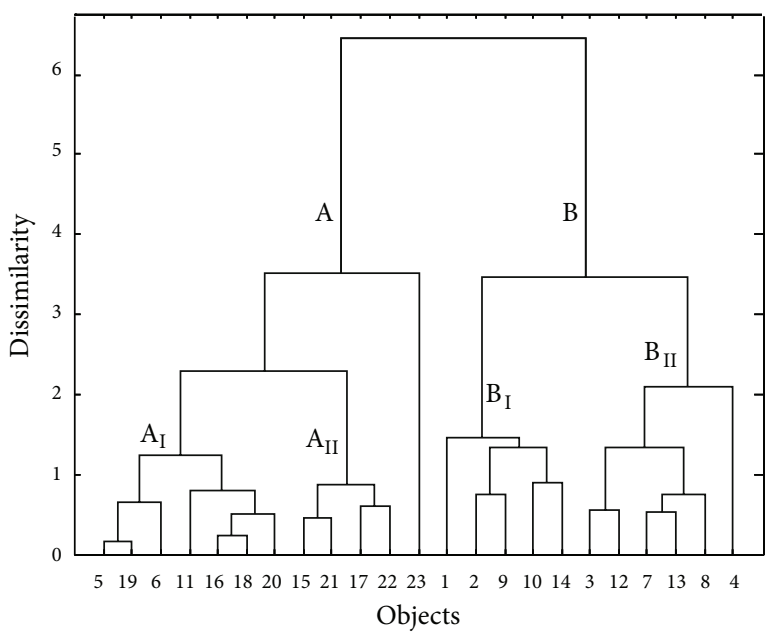

(a)

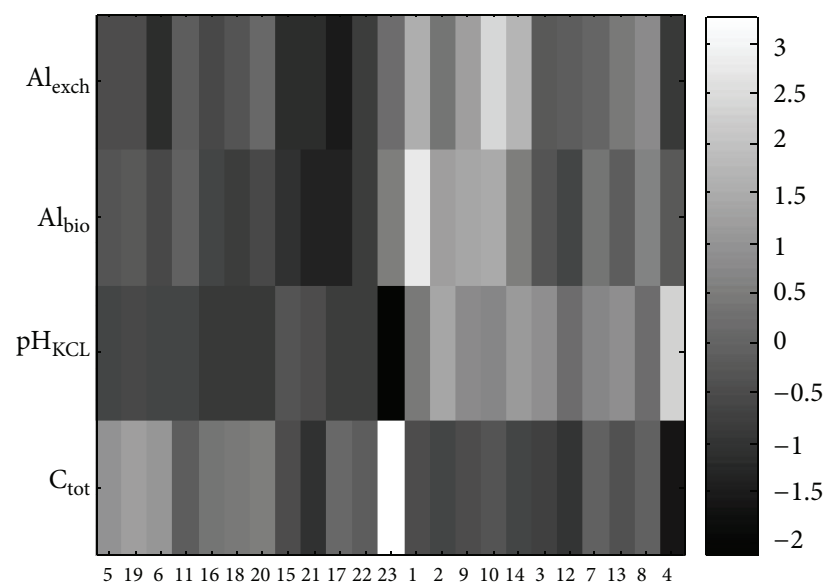

(b)

FIGURE 4: Dendrogram of samples with visual complement in the space of four parameters $\left(\mathrm{pH}_{\mathrm{KCl}}\right.$, total carbon content $\mathrm{C}_{\text {tot }}$, exchangeable aluminium content $\mathrm{Al}_{\text {exch }}$, and organically bound content $\mathrm{Al}_{\mathrm{pyr}}$ ).

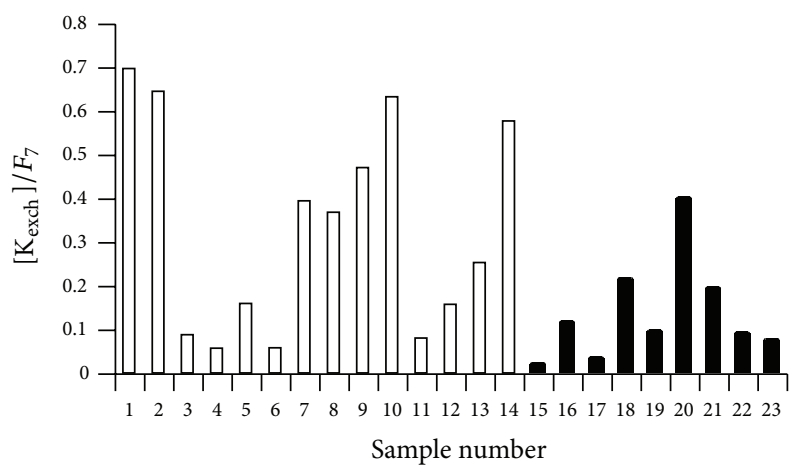

(a)

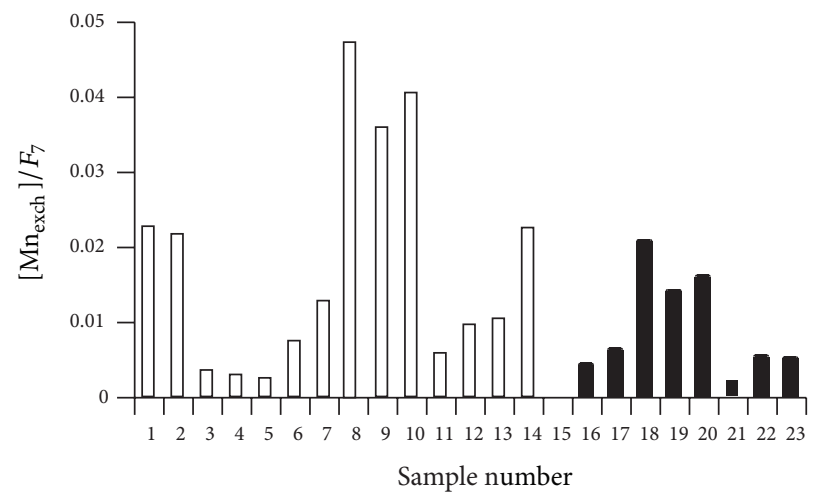

(c)

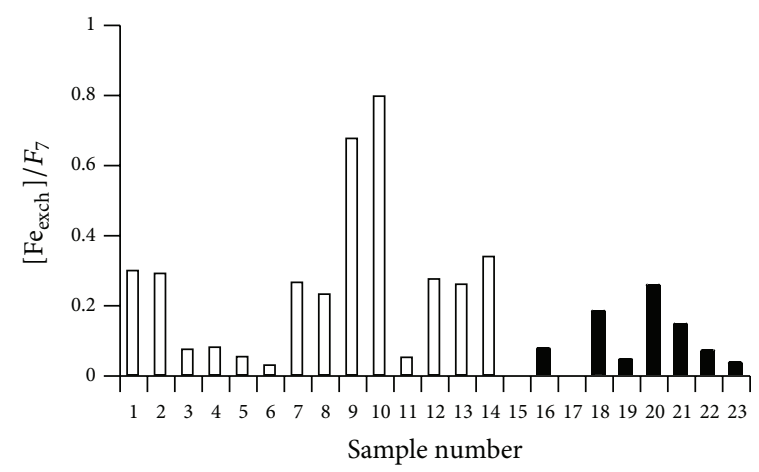

(b)

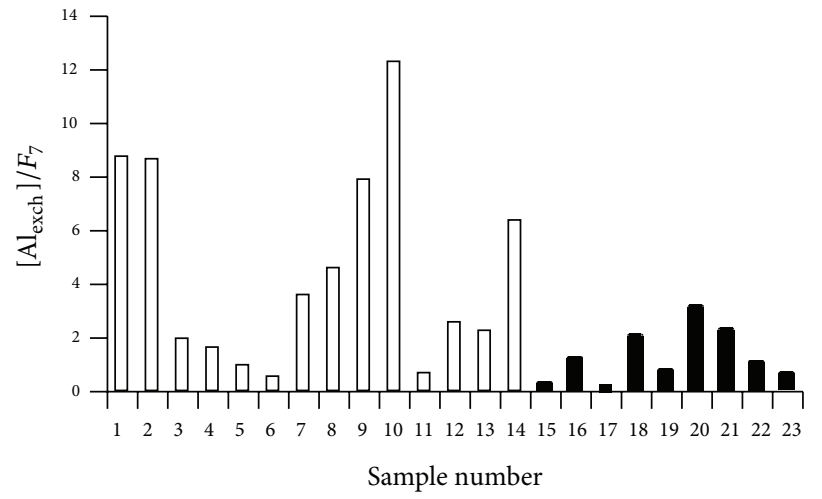

(d)

FIGURE 5: Molar ratios of selected metals in exchangeable complex in soil samples collected in Istebna (in white) and Bukowiec (in black).

the infected Istebna forest (objects numbers 5, 6, and 11), whereas in Cluster B all the remaining, soil samples from the Istebna forest were located. Two subclusters were also distinguished in each cluster; in cluster $A$, subcluster $A_{I}$ collecting soil samples numbers 5,6 , and 11 (from Istebna) and soil samples numbers 16, 18-20 (from Bukowiec) and subcluster $A_{\text {II }}$ composed of soil samples numbers 15, 17, 21 , and 22 (from Bukowiec) and one nongrouped in any subcluster soil sample no. 23 (from Bukowiec) and in cluster $B$, subcluster $B_{I}$, containing soil samples numbers $1,2,9,10$, and 14 and the subcluster $B_{\text {II }}$, including soil samples numbers $3,4,7,8,12$, and 13 . Based on the image of the data an 
TABLE 3: Chemical toxicity index.

\begin{tabular}{|c|c|c|c|c|c|c|c|c|}
\hline Sampling sites & No. & $F_{1}$ & $F_{2}$ & $F_{3}$ & $F_{4}$ & $F_{5}$ & $F_{6}$ & $F_{7}$ \\
\hline \multirow{14}{*}{ Istebna } & 1 & 0.020 & 0.032 & 0.019 & 0.131 & 0.168 & 0.015 & 0.621 \\
\hline & 2 & 0.013 & 0.028 & 0.013 & 0.116 & 0.152 & 0.007 & 0.476 \\
\hline & 3 & 0.046 & 0.026 & 0.043 & 0.117 & 0.156 & 0.026 & 1.792 \\
\hline & 4 & 0.033 & 0.020 & 0.031 & 0.088 & 0.138 & 0.019 & 1.679 \\
\hline & 5 & 0.223 & 0.068 & 0.175 & 0.456 & 0.513 & 0.089 & 3.289 \\
\hline & 6 & 0.372 & 0.083 & 0.261 & 0.563 & 0.629 & 0.109 & 4.460 \\
\hline & 7 & 0.161 & 0.155 & 0.130 & 0.426 & 0.503 & 0.086 & 1.040 \\
\hline & 8 & 0.060 & 0.060 & 0.054 & 0.201 & 0.261 & 0.036 & 0.996 \\
\hline & 9 & 0.026 & 0.041 & 0.023 & 0.126 & 0.217 & 0.016 & 0.643 \\
\hline & 10 & 0.018 & 0.036 & 0.017 & 0.105 & 0.174 & 0.012 & 0.518 \\
\hline & 11 & 0.397 & 0.074 & 0.270 & 0.591 & 0.675 & 0.142 & 5.335 \\
\hline & 12 & 0.050 & 0.036 & 0.043 & 0.147 & 0.258 & 0.025 & 1.389 \\
\hline & 13 & 0.145 & 0.078 & 0.115 & 0.335 & 0.455 & 0.067 & 1.865 \\
\hline & 14 & 0.055 & 0.062 & 0.050 & 0.207 & 0.264 & 0.034 & 0.892 \\
\hline \multirow{9}{*}{ Bukowiec } & 15 & 0.351 & 0.039 & 0.249 & 0.463 & 0.530 & 0.106 & 9.070 \\
\hline & 16 & 0.123 & 0.049 & 0.104 & 0.268 & 0.332 & 0.040 & 2.544 \\
\hline & 17 & 0.689 & 0.077 & 0.392 & 0.910 & 1.007 & 0.201 & 8.953 \\
\hline & 18 & 0.077 & 0.046 & 0.066 & 0.228 & 0.328 & 0.033 & 1.660 \\
\hline & 19 & 0.230 & 0.054 & 0.179 & 0.409 & 0.485 & 0.096 & 4.274 \\
\hline & 20 & 0.063 & 0.051 & 0.055 & 0.242 & 0.329 & 0.030 & 1.238 \\
\hline & 21 & 0.029 & 0.027 & 0.027 & 0.141 & 0.205 & 0.014 & 1.061 \\
\hline & 22 & 0.093 & 0.035 & 0.081 & 0.213 & 0.282 & 0.045 & 2.628 \\
\hline & 23 & 0.446 & 0.071 & 0.298 & 0.636 & 0.696 & 0.192 & 6.269 \\
\hline \multicolumn{2}{|c|}{ Boundary value } & $<1$ & $<0.1$ & $<0.05$ & & & $<0.05$ & \\
\hline
\end{tabular}

explanation of the differences between healthy and infected forests can be given. Soil samples from the Bukowiec (located in cluster $\mathrm{A}$ ) were characterized by relatively lower $\mathrm{pH}_{\mathrm{KCl}}$ and concentrations of $\mathrm{Al}_{\text {pyr }}$ and $\mathrm{Al}_{\text {exch }}$ than the remaining soil samples. Subcluster $A_{I}$ was distinguished mainly due to high concentration of $\mathrm{C}_{\text {tot }}$, whereas subcluster $\mathrm{A}_{\mathrm{II}}$ due to the lowest concentrations of $\mathrm{Al}_{\text {exch }}$ and $\mathrm{Al}_{\text {pyr }}$ among all the soil samples tested. The uniqueness of soil sample no. 23 in cluster A was caused by the lowest $\mathrm{pH}_{\mathrm{KCl}}$ and the highest concentration of $\mathrm{C}_{\text {tot}}$.

Soil samples from Istebna collected in cluster B were characterized by relatively higher $\mathrm{pH}_{\mathrm{KCl}}$ and low concentration of $\mathrm{C}_{\text {tot }}$. Moreover, the uniqueness of subcluster $\mathrm{B}_{\mathrm{I}}$ was caused by relatively higher concentrations of $\mathrm{Al}_{\text {exch }}$ and $\mathrm{Al}_{\text {pyr }}$. In subcluster $\mathrm{B}_{\mathrm{II}}$ soil sample no. 4 was characterized by the highest $\mathrm{pH}_{\mathrm{KCl}}$ and the lowest concentration of $\mathrm{C}_{\text {tot }}$ among all of the soil samples tested.

Values of chemical toxicity indexes $F_{1}-F_{5}$, calcium content $F_{6}=\mathrm{Ca}_{\text {exch }} /\left(\mathrm{Ca}_{\text {exch }}+\mathrm{Mg}_{\text {exch }}+\mathrm{K}_{\text {exch }}+\mathrm{Mn}_{\text {exch }}+\mathrm{Fe}_{\text {exch }}\right.$ $\left.+\mathrm{Al}_{\text {exch }}\right)^{-1}\left(\mathrm{cmol}_{\mathrm{c}} \mathrm{kg}^{-1}\right) /\left(\mathrm{cmol}_{\mathrm{c}} \mathrm{kg}^{-1}\right)$, and molar calcium to magnesium ratio $F_{7}=\mathrm{Ca}_{\text {exch }} / \mathrm{Mg}_{\text {exch }}\left(\mathrm{cmol} \mathrm{kg}^{-1}\right) /\left(\mathrm{cmol} \mathrm{kg}^{-1}\right)$ in CEC of soil are given in Table 3 . The values of $\mathrm{Ca}_{\text {exch }}\left(F_{1}<\right.$ 1) and $\operatorname{Mg}_{\text {exch }}\left(F_{2}<0.1\right)$ content in soil were low in both locations. More reliable criterion [31] is $F_{4}$, whose average value was higher in Bukowiec and equaled 0.4. The values of $\mathrm{F}_{3}$ computed for samples collected in Bukowiec, except for point 21 , were higher than the critical value of 0.05 . The results for samples from Istebna were ambiguous (for eight points $F_{3} \leq 0.05$ and for six points $F_{3}>0.05$ ). It can be claimed that the toxic properties of aluminium were affected also by the iron content in the exchangeable complex. The sum of aluminium and iron content in CEC was on average higher in Istebna samples than in Bukowiec. An average values of $F_{5}$ and $F_{6}$ were higher in Bukowiec. Soil samples differed also in terms of $F_{7}$ coefficient values, which were on average higher in Bukowiec than in Istebna.

Interestingly, the results of molar ratios in CEC, computed as quotient of metal content $\left(\mathrm{K}_{\text {exch }}, \mathrm{Fe}_{\text {exch }}, \mathrm{Mn}_{\text {exch }}\right.$, and $\mathrm{Al}_{\text {exch }}$ ), and $F_{7}$ coefficient (Figure 5) were higher for soil samples collected in Istebna, particularly for iron and aluminium. The composition of an exchangeable complex seems to be the reason for different status of aluminium in soil samples of Bukowiec and Istebna.

\section{Summary}

The hierarchical clustering methods have shown that the examined two areas of spruce forests in the Silesian Beskid with diametrically different health status differ in four chemical properties of the soil taken from the $\mathrm{O}$ level. First of all, the soil in the healthy forest (Bukowiec) contains $30 \%$ less exchangeable aluminium and more organic matter. Furthermore, it was found that this soil was more acid. $\mathrm{Al}_{\text {pyr }}$ aluminium content is higher in the devastated forest area 
(Istebna). In addition, it was found that the absolute values of the cation exchange capacity of the soil in both regions were similar, but the molar ratio of metals in CEC was different.

Release of potentially toxic $\mathrm{Al}$ forms is very important consequence of soil acidification that may significantly contribute to forest extinction. Though concentrations of acidificants in atmosphere have decreased in the last decades (particularly $\mathrm{SO}_{4}$ ), forests are still endangered by long-term changes of soil conditions. It can be assumed that the high exchange $\mathrm{Al}$ form concentration in Istebna soil is one of the reasons for dying spruces. Weakened trees fall ill and are unable to defend themselves against insect pests.

The exchangeable aluminium content is lower in soils from Bukowiec. The composition of the CEC is more favorable which may explain much better condition of the forest.

\section{Conflict of Interests}

The authors declares that there is no conflict of interests regarding the publication of this paper.

\section{References}

[1] B. Ulrich, R. Mayer, and P. K. Khanna, "Chemical changes due to acid precipitation in a loess-derived soil in central Europe," Soil Science, vol. 130, no. 4, pp. 193-199, 1980.

[2] O. Drábek, L. Mládková, L. Borůvka, J. Szakova, A. Nikodem, and K. Nemecek, "Comparison of water-soluble and exchangeable form of $\mathrm{Al}$ in acid forest soils," Journal of Inorganic Biochemistry, vol. 99, pp. 1788-1795, 2005.

[3] H. Klöppel, A. Fliedner, and W. Kördel, "Behaviour and ecotoxicology of aluminium in soil and water-review of the scientific literature," Chemosphere, vol. 35, no. 1-2, pp. 353-363, 1997.

[4] M. Kotowski, L. Pawłowski, and X. Zhu, Aluminum in Environment, Wydawnictwo Politechniki Lubelskiej, Lublin University of Technology Publishing House, Lublin, Poland, 1995, (Polish).

[5] J. P. Boudot, T. Becquer, D. Merlet, and J. Rouiller, "Aluminium toxicity in decling forests: a general overview with a seasonal assessment in a silver fir forest in the Vosges Mountains (France)," Annales des Sciences Forestieres, vol. 51, no. 1, pp. 2751, 1994.

[6] O. Drábek, L. Borůvka, L. Mládková, and M. Kocarek, "Possible method of aluminium speciation in forest soils," Journal of Inorganic Biochemistry, vol. 97, pp. 8-15, 2003.

[7] T. B. Kinraide, "Reconsidering the rhizotoxicity of hydroxyl, sulphate, and fluoride complexes of aluminium," Journal of Experimental Botany, vol. 48, no. 310, pp. 1115-1124, 1997.

[8] E. Matczak-Jon, "The role of aluminium in the environment," Chemical News, vol. 49, pp. 9-10, 1995 (Polish).

[9] P. Matúš, "Evaluation of separation and determination of phytoavailable and phytotoxic aluminium species fractions in soil, sediment and water samples by five different methods," Journal of Inorganic Biochemistry, vol. 101, no. 9, pp. 1214-1223, 2007.

[10] P. Matúš, J. Kubová, M. Bujdoš, and J. Medved, "Free aluminium extraction from various reference materials and acid soils with relation to plant availability," Talanta, vol. 70, no. 5, pp. 996$1005,2006$.

[11] L. Mládková, L. Borůvka, O. Drábek, and R. Vasat, "Factors influencing distribution of different $\mathrm{Al}$ forms in forest soils of the Jizerskè hory Mts," Journal of Forest Science, vol. 52, pp. 8792, 2006.

[12] V. Manoharan, P. Loganathan, R. W. Tillman, and R. L. Parfitt, "Interactive effects of soil acidity and fluoride on soil solution aluminium chemistry and barley (Hordeum vulgare L.) root growth," Environmental Pollution, vol. 145, no. 3, pp. 778-786, 2007.

[13] Z. Rengel, "Aluminium cycling in the soil-plant-animal-human continuum," BioMetals, vol. 17, no. 6, pp. 669-689, 2004.

[14] C. S. Cronan and D. F. Grigal, "Use of calcium/aluminum ratios as indicators of stress in forest ecosystems," Journal of Environmental Quality, vol. 24, no. 2, pp. 209-226, 1995.

[15] H. A. De Wit, J. Mulder, P. H. Nygaard, and D. Aamlid, “Testing the aluminium toxicity hypothesis: a field manipulation experiment in mature spruce forest in Norway," Water, Air, and Soil Pollution, vol. 130, no. 1-4, pp. 995-1000, 2001.

[16] H. A. de Wit, J. Mulder, P. H. Nygaard et al., "Aluminum: the need for a re-valuation of its toxicity and solubility in mature forest stands," Water Air Soil Pollution Focus, vol. 1, pp. 103-118, 2001.

[17] J. Aherne, E. P. Farrell, J. Hall, B. Reynolds, and M. Hornung, "Using multiple chemical criteria for critical loads of acidity in maritime regions," Water Air Soil Polluttion Focus, vol. 1, pp. 7590, 2002.

[18] K. Hansen, L. Vesterdal, A. Bastrup-Birk, and J. Bille-Hansen, "Are indicators for critical load exceedance related to forest condition?" Water, Air, and Soil Pollution, vol. 183, no. 1-4, pp. 293-308, 2007.

[19] A. Göttlein, A. Heim, and E. Matzner, "Mobilization of aluminium in the rhizosphere soil solution of growing tree roots in an acidic soil," Plant and Soil, vol. 211, no. 1, pp. 41-49, 1999.

[20] M. Holmberg, J. Mulder, M. Posch et al., "Critical loads of acidity for forest soils: tentative modifications," Water Air Soil Pollution Focus, vol. 1, pp. 91-101, 2001.

[21] http://www.katowice.pios.gov.pl/monitoring/informacje/ stan2012/rapimgw.pdf.

[22] A. Smoliński, M. Zołotajkin, J. Ciba, P. Dydo, and J. Kluczka, "PLS-EP algorithm to predict aluminum content in soils of Beskid Mountains region," Chemosphere, vol. 76, no. 4, pp. 565571, 2009.

[23] M. Zołotajkin, J. Ciba, J. Kluczka, M. Skwira, and A. Smoliński, "Exchangeable and bioavailable aluminium in the mountain forest soil of Barania Góra Range (Silesian Beskids, Poland)," Water, Air, and Soil Pollution, vol. 216, no. 1-4, pp. 571-580, 2011.

[24] A. Ostrowska, S. Gawliński, and Z. Szczubiałka, Methods for Analyzing and Assessing the Properties of Soil and Plants, Institute of Environmental Protection, Warszawa, Poland, 1991, (Polish).

[25] ISO, "11260 Soil quality-determination of effective cation exchange capacity and base saturation degree, using barium chloride solution".

[26] G. P. Gillman, "A proposed method for the measurement of exchange properties of highly weathered soils," Australian Journal of Soil Research, vol. 17, pp. 129-139, 1979.

[27] J. A. Hartigan, "Statistical theory in clustering," Journal of Classification, vol. 2, no. 1, pp. 63-76, 1985.

[28] L. Kaufman and P. J. Rousseeuw, Finding Groups in Data, an Introduction to Cluster Analysis, John Wiley \& Sons, New York, NY, USA, 1990.

[29] D. L. Massart and L. Kaufman, The Interpretation of Analytical Data by the Use of Cluster Analysis, John Wiley \& Sons, New York, NY, USA, 1983. 
[30] A. Smoliński, B. Walczak, and J. W. Einax, "Hierarchical clustering extended with visual complements of environmental data set," Chemometrics and Intelligent Laboratory Systems, vol. 64, no. 1, pp. 45-54, 2002.

[31] L. Borůvka, V. Podrázsky, L. Mládková, I. Kuneš, and O. Drábek, "Some approaches to the research of forest soils affected by acidification in the Czech Republic," Soil Science \& Plant Nutrition, vol. 50, no. 5, pp. 745-749, 2005. 

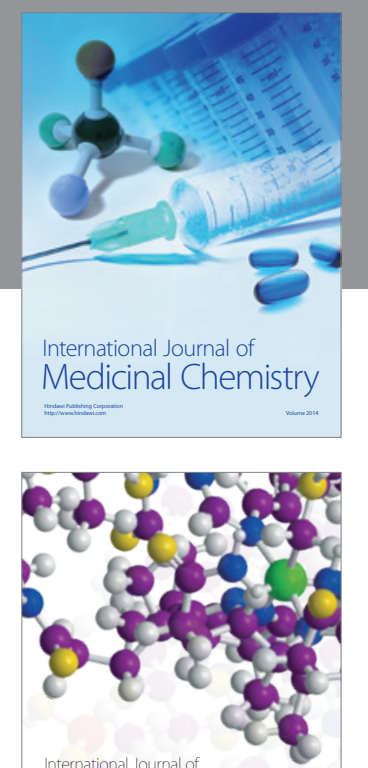

\section{Carbohydrate} Chemistry

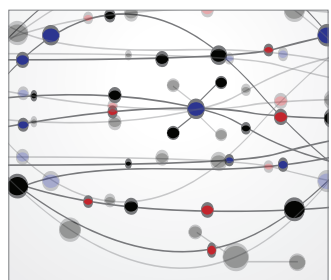

The Scientific World Journal
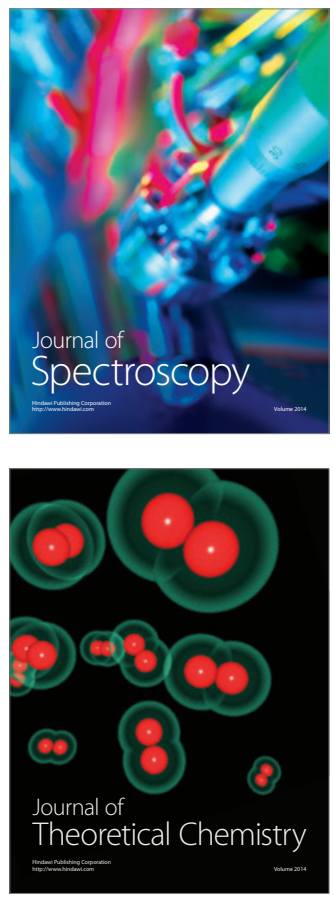
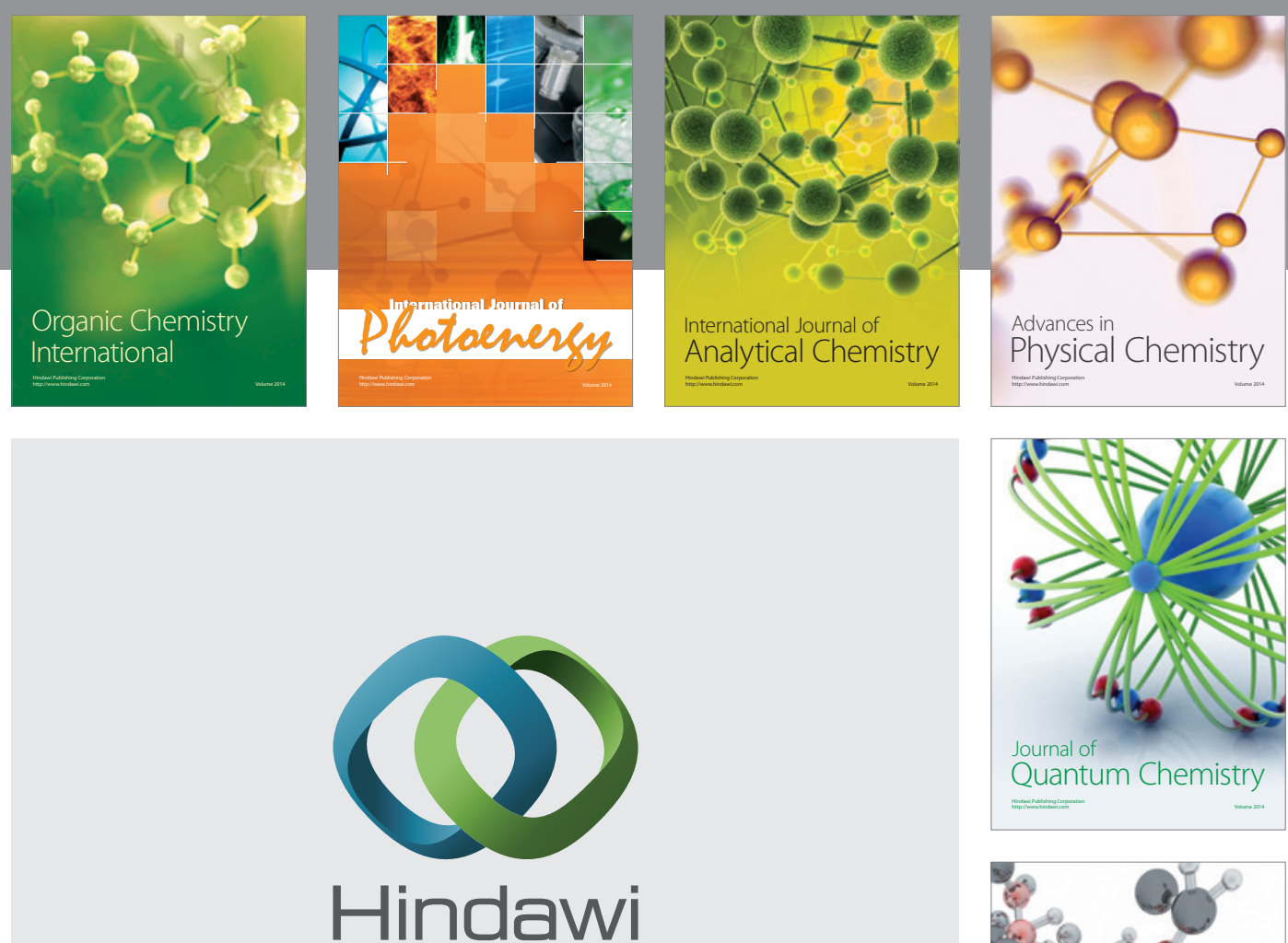

Submit your manuscripts at

http://www.hindawi.com

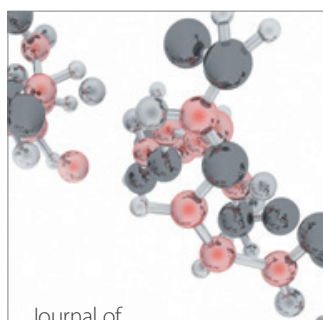

Analytical Methods

in Chemistry

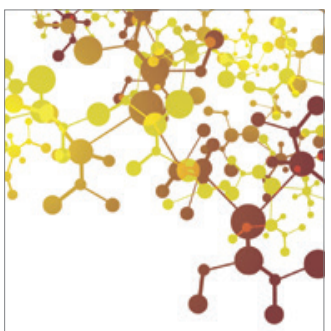

Journal of

Applied Chemistry

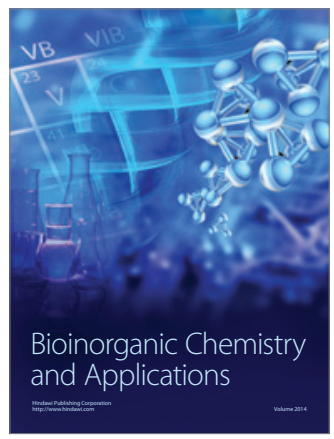

Inorganic Chemistry
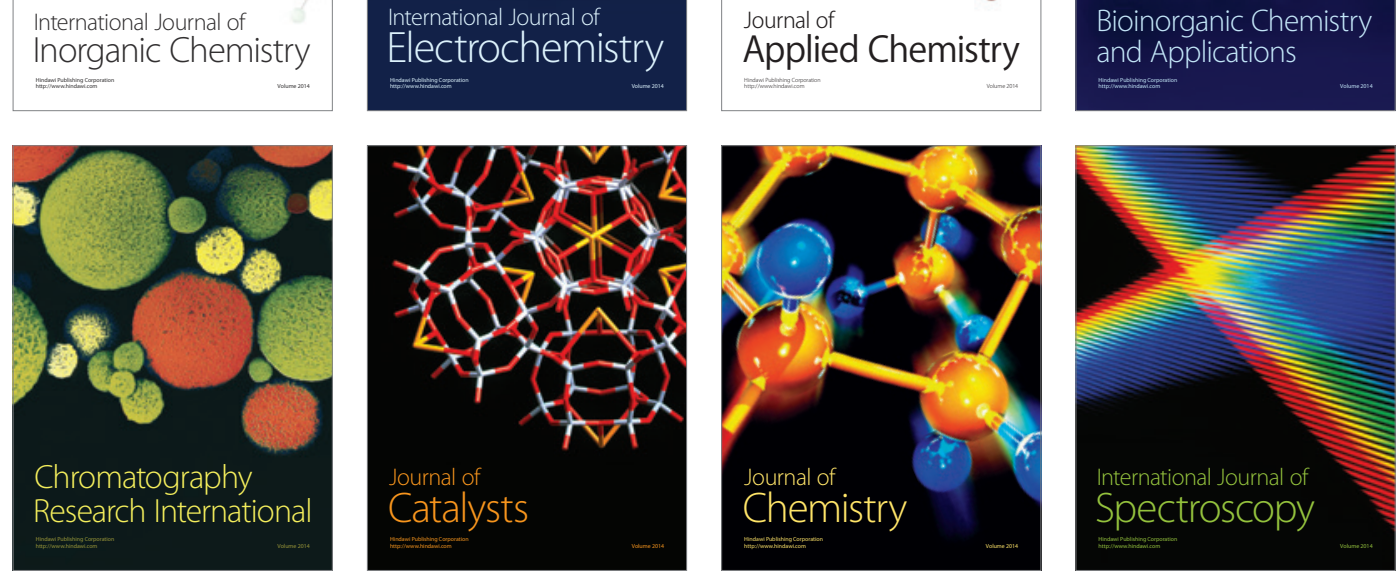